\title{
Optimal Power Point on the I-V Curve of a Photovoltaic Solar System (Modelling and Analysis)
}

\author{
Baba Alfa ${ }^{\mathrm{a}}$, Yakubu Adamu ${ }^{\mathrm{a}, *}$, Daniel Alberto Pena Perez ${ }^{\mathrm{b}}$ \\ ${ }^{a}$ Department of Physics, Ibrahim Babangida University, Lapai Niger State Nigeria. \\ ${ }^{b}$ Av, paseo Oriente 950, Cd Industrial, 36541, LAPEM Irapuato Guanajuato México
}

\begin{abstract}
Motivated by recent interest in improving the performance of PV cells, we explored the optimal power point in Photovoltaic (PV) cells by using three different topologies to compare its function and efficacy. Firstly, we investigate the consequence of connecting a PV directly to the load. Secondly, the efficacy of an electronic device that generates a pulse width modulation (PWM) to control a boost converter connected to the PV panel and the load and finally the maximum power point tracking (MPPT) method by using the Algorithm Perturb and Observe (P\&O), with the implementation of the DC-DC converter between the PV panel and the load. In doing so, a mathematical model of the PV cell was employed and using MATLAB Simulink, the behaviour of the voltage and current signals acquired were analysed, this helps in understanding the performance of the solar cell under different meteorological circumstances, and its effect on the power generated by the PV cell. Finally, based on the performance simulations on the three methods implemented, the results were tested for the response time of the MPPT under different load conditions in order to ascertain it performance.
\end{abstract}

Keywords: Photovoltaic cell, perturb \& observe (P\&O), MPPT, Load.

Article History :

Received: 16 February 2020

Received in revised form: 05 May 2020

Accepted for publication: 06 May 2020

Published: 14 May 2020

(C)2020 Journal of the Nigerian Society of Physical Sciences. All rights reserved. Communicated by: B. J. Falaye

\section{Introduction}

In the last two decades, the field of photovoltaic has made a profound impact in it widespread use, this represents a good progress from a stand-alone PV to a utility interactive system. Despite the remarkable growth of this technology, it's often characterized with low efficiency, which are mostly due to bad solar orientation or adaptation which makes it difficult to extract maximum output power from the PV panel [1].

It is a proven fact that $\mathrm{PV}$ panels have a non-linear characteristic $(I=f(V))$ with a single point where the power generated is maximum (MPP). This maximum power point strongly

\footnotetext{
${ }^{*}$ Corresponding author tel. no: 08034511406

Email address: yaakubu@ibbu.edu.ng (Yakubu Adamu)
}

depends on the intensity of solar radiation and the temperature of the location, which changes during the day [2]. Such nonlinearity in the characteristic of a PV panel will give rise to a perfect non-coupling between photovoltaic generator (GPV) and the load, thus, creating a problem of transferring the maximum power from the photovoltaic generator (GPV) to the load [3]. Therefore, it becomes difficult under these scenarios to extract the maximum output power that could be available at any given weather condition. To get around these problems and extract the maximum power available at the GPV terminals and transfer it to the load at any weather condition all times, an MPPT scheme that responds to the weather changes and obtains the highest possible energy at each moment is necessary. Though there have been many research approaches in the liter- 
ature that have been tested and implemented, ranging from the simplest method like Disrupt \& Observer (D \& O), Estimate, Perturb and Perturb (EP \&P), Modified Perturb and Observe (MP\&O). etc. to more complex methods, none have reached the desired potential [4].

In this paper, we explored different topology to achieve the optimal power point on a PV cell using the maximum power point tracking (MPPT) method which is controlled and implemented by the Perturb and Observe $(\mathrm{P} \& \mathrm{O})$ algorithm. This method is intended to track the point of maximum energy generated by the PV panel according to the weather variations. Therefore, to show the effectiveness of the method compare with others, a MATLAB Simulink model was used for the numerical analysis of different values of irradiation and temperature and for the analysis of the relationship of module parameters with characteristics curves of PV module.

\section{PV Model Formulation and Equations of the PV Module}

In the model formulation, we consider a single-diode model for the PV module, which consists of a few PV cells basically a p-n diode, connected both in series and parallel to obtain the desired voltage. The circuit model is designed to show agreement between a current source and diode such that it can be used to calculate the power supplied by the GPV under all irradiation and temperature conditions (figure 1) [5].

For simplicity, $I_{s c}$ (in Figure 1) is the current of the source otherwise known as the cell photocurrent $I_{s c}$ while $\mathrm{R}_{s h}$ and $\mathrm{R}_{s}$ are, respectively, the intrinsic shunt and series resistances of the solar cell.

\subsection{Equations of the PV Module}

The mathematical equations that described the relationship between the cell terminal current $(\mathrm{A})$ and voltage $(\mathrm{V})$ is given by [6], such relationship is based on I-V curve characteristics of the solar cell and PV module, and a generalization from Shockley ideal diode equation lead to the following equations:

$I_{D}=I_{o}\left[\exp \left(\frac{q V_{D}}{n N_{s} k_{B} T}\right)-1\right]$,

where $I_{D}$ is the current through the diode, $I_{o}$ is the value of the saturation current, and it depends on the temperature, $q$ is the absolute value of the electron's charge, $n$ represent the quality factor of the diode that is used as adjustment parameter, which ranges between 1 to $5\left(\mathrm{n}=1\right.$ for the ideal diode model), $N_{s}$ is the number of cells that are connected in series, $\mathrm{T}$ is the P-N junction temperature that is generally assumed to be close to the temperature of the cell [7].

Now, based on the circuit for single-diode model (Figure 1), the current flowing through the parallel resistor $I_{P}$, is given by:

$I_{P}=\frac{V+R_{S} I}{R_{s h}}$.

Then, analysis of the total current in Figure 1 will provide equation (3)

$I=I_{P h}-I_{D}-I_{P}$,

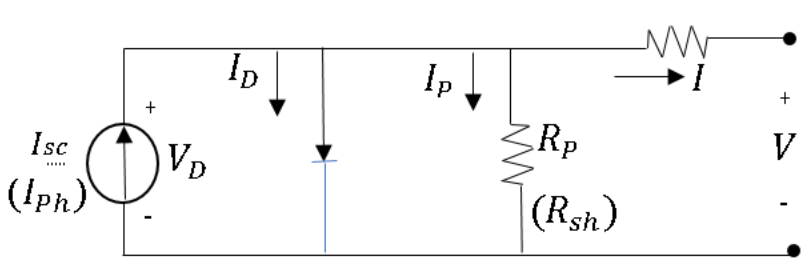

Figure 1: Equivalent Circuit for Single-Diode Model of Solar Cell [8].

where, $I_{P h}$ is the current of the source, $I_{D}$ the current of the diode, $I_{P}$ current in the parallel resistor and $I$ represents the current through the series resistors. Substituting the Equation (1) and (2) into Equation (3), and considering that $V_{D}=V+I_{R S}$, this leads to a generalization (based on Shockley ideal diode equation) given as:

$I=I_{P h}-I_{o}\left[\exp \left(\frac{q V+I R_{s}}{n N_{s} k_{B} T}\right)-1\right]-\frac{V+R_{S} I}{R_{s h}}$

Here, equation (4) is used for the numerical methods to find the electrical current value.

\subsection{Equations for Open-Circuit Voltage and Short-Circuit Cur- rent}

In the model, there are two critical parameters to measure, the open-circuit voltage and the short circuit current. While, the short-circuit current is affected by the solar radiation, the temperature condition affects the open-circuit voltage [8]. Therefore, from theory of semiconductors and photovoltaic, PV cells can be characterized base on the operational point, such as the short-circuit point where $I=I_{s c}$ and $V=0$, open-circuit point where $V=V_{o c}$ and $I=0$, and the maximum power point where $V=V_{m p p}$ and $I=I_{m p p}$, these conditions can enhance the achievement of maximum electrical power[9]. Therefore, considering equation (4), it is possible to determine the $I_{s c}$, using the condition that $V=0$ and $I=I_{s c}$ this leads to the equation (5):

$I_{S C}=I_{P h}-I_{O}\left[\exp \left(\frac{q\left(R_{s} I_{s c}\right)}{n N_{s} k_{B} T}\right)-1\right]-\frac{R_{s} I_{s c}}{R_{s h}}$,

where, $I_{S C}$ is the short-circuit current in the model (Figure 1). Thus, to obtain the equation for open circuit point $V_{O C}$ we consider the condition that $I_{0 c}=0$.

$I_{O C}=0=I_{P h}-I_{o}\left[\exp \left(\frac{q\left(V_{o c}\right)}{n N_{s} k_{B} T}\right)-1\right]-\frac{V_{o c}}{R_{s h}}$

From the conditions that $V=V_{m p p}$ and $I=I_{m p p}$, (which permit that the maximum electrical power to be achieved), it can be deduce that:

$I_{m p p}=I_{P h}-I_{o}\left[\exp \left(\frac{q\left(V_{m p p}+R_{s} I_{m p p}\right)}{n N_{s} k_{B} T}\right)-1\right]-\frac{V_{m p p}+R_{s} I_{m p p}}{R_{s h}}(7)$

Equation (7) suggests that a PV cell may have a hybrid behaviour, which may depend on the values of open-circuit point and short current point, where every region is characterized by 
an asymptote in their respective axis [9]. Therefore, it is possible to use the tangent of the relationship of I-V curve, to evaluate the transition from the current source to the voltage source controller regions. In that respect, we considered the analysis from Equation (4), which lead to the mathematical expression as:

$$
\begin{aligned}
& \frac{d I}{d V}=\frac{-q I_{o}}{n N_{s} k_{B} T}\left(1+\frac{d I}{d V} * R_{s}\right) * \exp \left[\frac{-q\left(V+R_{s} I\right.}{n N_{s} k_{B} T}\right] \\
& -\frac{1}{R_{s h}}\left(1+\frac{d I}{d V} * R_{s}\right)
\end{aligned}
$$

Where the $\frac{d I}{d V}$ is the derivative of the current with respect to the voltage that is evaluated at the maximum power point, hence, from ohm's law for power, we see that at any point on the I-V curve $P=I V$. The derivative $\frac{d I}{d V}$ (equation (8)) must be equal to zero to be able evaluate the maximum point values. Therefore;

$\frac{d P}{d V}=V \frac{d I}{d V}+I=0$

Furthermore, if equation (9) is the maximum power value and equated to zero, then the equation can be written as

$\frac{d P}{d V}=-\frac{I_{m p p}}{V_{m p p}}$

Where $I_{m p p}$ is the current (A), and $V_{m p p}$ the voltage (V), both at the maximum power point. Also, from the equation (8), it we can be deducted that equation 11

$$
\begin{aligned}
& -\frac{I_{m p p}}{V_{m p p}}=\frac{-q I_{o}}{n N_{s} k_{B} T}\left(1-\frac{I_{m p p}}{V_{m p p}} * R_{s}\right) * \exp \left[\frac{q\left(V_{m p p}+R_{s} I_{m p p}\right.}{n N_{s} k_{B} T}\right] \\
& -\frac{1}{R_{s h}}\left(1-\frac{I_{m p p}}{V_{m p p}} * R_{s}\right)
\end{aligned}
$$

represents the mathematical equation for the maximum power point voltage and current, which can be solved numerically. The photodiode current or photocurrent $I_{p h}$ can be determined using the mathematical expression for open circuit voltage in equation (6), taking into account (to neglect) the term ' -1 ' of the Shockley equation (Equation 1), this is because, in silicon devices the dark saturation current is lower than the exponential term value [10], thus the equation is expressed as:

$I_{p h}=\frac{V_{o c}}{R_{s h}}+I_{o}\left[\exp \left(\frac{q V_{o c}}{n N_{s} k_{B} T}\right)\right]$

Then, by inserting equation (12) into equation (5), to obtain $I_{S C}$, which is expressed

$I_{S C}=\frac{V_{o c}-R_{s} I_{S C}}{R_{s h}}+I_{o}\left[\exp \left(\frac{q V_{o c}}{n N_{s} k_{B} T}\right)\right]$

And solving equation (13) to obtain the value of $I_{o}$ as:

$I_{o}=\left(I_{S C}-\frac{V_{o c}-R_{s} I_{S C}}{R_{s h}}\right) * \exp \left[-\left(\frac{q V_{o c}}{n N_{s} k_{B} T}\right)\right]$

Similarly, inserting equation (14) into equation (12), to obtain:

$I_{p h}=I_{S C}\left(\frac{R_{s h}-R_{s}}{R_{s h}}\right)$
Equation (15) represents the value of the photodiode current $I_{p h}[\mathrm{~A}]$, which is a light generated current that depends on three factors, shunt resistance $\left(R_{s h}\right)$, series resistance $\left(R_{s}\right)$ and shortcircuit current $\left(I_{S C}\right)$ and as well depend linearly on solar irradiance.

\subsection{Reverse Saturation Current}

The module reverse saturation current $I_{r s}$ exhibit a certain behaviour when the diode is operating in the reverse bias region, thus the equation of such behaviour is represented as:

$I_{r s}=\frac{I_{S C}}{\exp \left(n N_{s} k_{B} T\right)-1}$

This (Equation 16) depends on short circuit current, open circuit voltage and influenced by the changed in temperature [10]. Such temperature dependence of the diode saturation current is also given as;

$I_{t r s}=I_{r s}\left(\frac{T_{o}}{T_{C}}\right)^{3} * \exp \left[\frac{q E_{g}}{k n}\left(\frac{1}{T_{0}}-\frac{1}{T_{C}}\right)\right]$,

where $I_{t r s}$ is the temperature dependent reverse saturation current and $E_{g}$ is the band gap energy. The photocurrent generated in the solar cell generally depend on temperature and solar irradiance as such the value of the saturation current varies linearly and proportional to the solar radiation. Thus, equation (18) describes the saturation effect as:

$I_{p h}=\left[I_{S C}+K_{S C}\left(T_{C}-T_{O} * \frac{G}{G_{S}}\right)\right]$,

where $K_{S C}$ is short circuit current temperature coefficient and $G_{S}$ is the solar irradiance at standard test conditions, $G$ is the operating radiation condition, $T_{C}$ is the temperature at standard conditions $(K)$ and $T_{O}$ is the operating cell temperature $(K)$.

The Equations (6), (5), (11) are needed to solve the parameters $I_{p h}, I_{o}, R_{S}$ and $R_{S h}$. Therefore, to find the numerical values of the all the equations $\left(V_{o c}, I_{S C}, V_{m p p}\right.$ and $\left.I_{m p p}\right)$ a NewtonRaphson technique is used to get the quantitative values. Also, a maximum power point equation $\left(P_{m p p}=V_{m p p} * I_{m p p}\right)$ was utilized and the detailed Simulink model of all the parameters were analysed. The value of module short-circuits current $I_{S C}$ is taken from the field experimental procedures.

\section{Implementation and Analysis (environmental and elec- trical effects)}

The mathematical model used depend on factors that varies according to environmental conditions such as temperature and irradiance and those factors that also depend on electrical parameters. To analyse the effects of these factors, MATLAB Simulink with SOLAREX MSX-60 specification values were used (See Appendix table A.1). These values are based on the commercial polycrystalline silicon cells from SOLAREX with a parallel string of 36 solar cells [11]. This is because polycrystalline cells are the most used in the market and so accommodate changes in a better way [12]. Furthermore, the algorithm of $\mathrm{P} \& \mathrm{O}$ is implemented to evaluate current and voltage points 

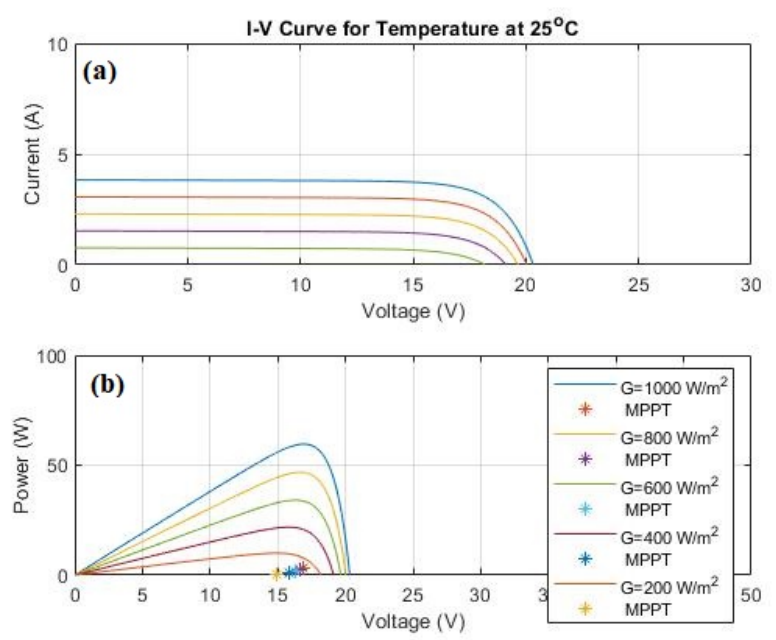

Figure 2: (a) I-V curve Under Variable Radiation. Appendix C.2 (b). P-V curve Under Variable Radiation. Appendix C.2.

continuously under a changing weather or electrical variations and the maximum power point (MPP) was found at every moment in time.

\subsection{Effect of Solar Variation}

The variational effects of solar radiation $\left(1000-200 \mathrm{~W} / \mathrm{m}^{2}\right)$ on voltage, current and power were observed at a temperature of $25^{\circ} \mathrm{C}$ (Table 1 ). The maximum power reached under different irradiance values from $1000-200 \mathrm{~W} / \mathrm{m}^{2}$ was $59.59 \mathrm{~W}$ at $1000 \mathrm{~W} / \mathrm{m}^{2}$, as such, the voltage changes from $20.32 \mathrm{~V}$ to 18.2 $\mathrm{V}$ representing a change of $9.10 \%$ while current changes from 3.83 A to 0.86 A representing a drop of $23.88 \%$ of the maximum energy possible, this happened at the $20.00 \%$ of the total irradiance.

The I-V curve of the changes in the irradiance from $200 \mathrm{~W} / \mathrm{m}^{2}$ to $1000 \mathrm{~W} / \mathrm{m}^{2}$ at a constant temperature $25^{\circ} \mathrm{C}$ (figure $2 \mathrm{a}$ ) shows that the value of the MPPT current increases at higher irradiance values and decreases at lower irradiance.

Similarly, the P-V curve (figure 2b), describes the maximum power achieved based on the values for irradiation. Here, the value of the power increases with increasing values of irradiance and voltage. Thus, the maximum power achieved on the changing irradiance for this model was at $59.59 \mathrm{~W}$ at 1000 $\mathrm{W} / \mathrm{m} 2$, this is akin to the findings in [13].

\subsection{Effects of Temperature Variation}

It is a well-known fact that the PV cells are susceptible under the influence of temperature change. Table 2 is indicative of the behaviour of PV cells under a changing temperature, an indication that those changes are not linear.

To represent the effect of temperature variation at a constant irradiance $\left(1000 \mathrm{~W} / \mathrm{m}^{2}\right)$, the numerical calculations (Figures 3a $\& 3$ b. ) were plotted to observe the behaviour. Firstly, the value of the current changes very slightly while the value of the voltage has a significant change in the different values of the temperatures, from $0^{\circ} \mathrm{C}$ to $40^{\circ} \mathrm{C}$. (Figures $2 \mathrm{~b}, 3 \mathrm{a}, 3 \mathrm{~b}$ ).
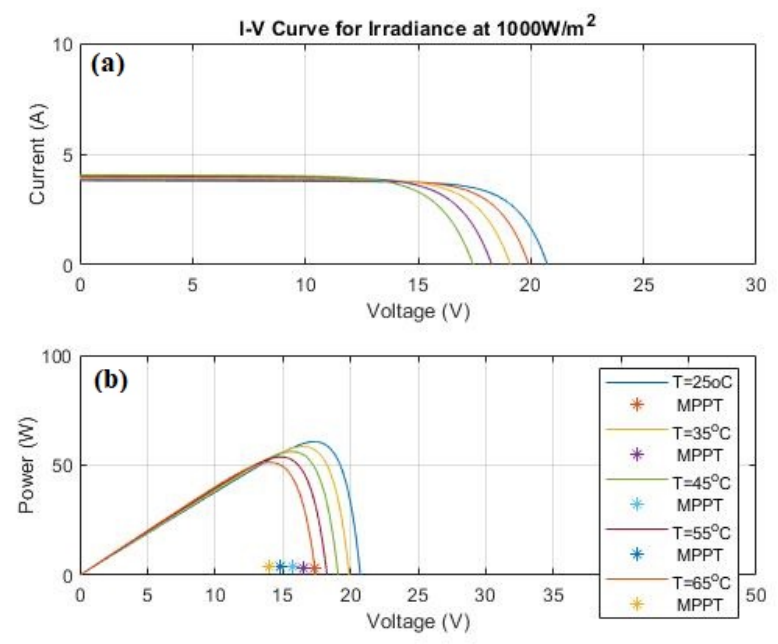

Figure 3: (a) I-V Curve at Constant Radiation (b) P-V Curve at Constant Radiation

On the other hand, the value of the power varies accordingly as the temperature increases, thereby making the voltage to drop while the current increases. Hence, the best performance (efficiency) occurred at low temperatures conditions with high irradiance. The energy production drops when the panel reaches high temperature as such the PV panel works most effciently in cold temperatures. Hence, it can be deduced that, even under cold and sunny environment, this model of the $\mathrm{PV}$ cells will perform to it maximum.

\subsection{Effects of Electrical Parameters}

Electrical parameters in a PV system such as resistors (shunt or series) can affect the performance of the solar cell considerably, such parameters tends to reduce the efficiency of the solar cell by dissipating power in the resistance. The most common parasitic resistances are the shunt and series resistors (Figure 1 ), both are not strictly constant with respect to temperature changes [14].

\subsection{Effects of Variation of Shunt Resistor}

The presence of the shunt resistance $\mathrm{R}_{s h}$ can reduce the power output of the PV cell, this power loss arises from the imperfections on the surface of the solar cell (or in bulk) and by leakage current across the edge of the cell. The efficiency of the cell decreases when the value of the Shunt resistor decreases [14]. Therefore, it is possible to approximate the value of $\mathrm{R}_{s h}$ to the slope of $\mathrm{I}_{S C}$. In Figure $4 \mathrm{a} \& 4 \mathrm{~b}$ (I-V curve of the PV from 5 $\Omega$ to $500 \Omega$ ), the small resistance values show that the curve is not a perfect curve, but as the values of the resistance increases higher than $100 \Omega$, a proper I-V curve was observed.

It noteworthy that the level of the output power remains low when $R_{s h}$ values are lower than $100 \Omega$, as such the efficiency can be affected for an incorrect value of $\mathbf{R}_{s h}$, hence, the importance of calculating $\mathrm{R}_{s h}$ correctly.

Table 3 shows the performance of the power output, in this case, the resistance values from 5-500 ohms were used. The IV curve (Figure 5), which is almost linear for some parameters 
Table 1: Analysis of Voltage, Current and Power Under Solar Radiation Changes at $25^{\circ} \mathrm{C}$.

\begin{tabular}{lccccr}
\hline Irradiance $\left(\mathrm{W} / \mathrm{m}^{2}\right)$ & $\mathrm{V}_{o c}(\mathrm{~V})$ & $\mathrm{I}_{S C}(\mathrm{~A})$ & MPPT Voltage $(\mathrm{V})$ & MPPT Current $(\mathrm{A})$ & MPPT Power $(\mathrm{W})$ \\
\hline 1000 & 20.32 & 3.83 & 16.93 & 3.52 & 59.59 \\
800 & 20.03 & 3.06 & 16.65 & 2.80 & 46.60 \\
600 & 19.66 & 2.29 & 16.3 & 2.09 & 34.06 \\
400 & 19.20 & 1.53 & 15.79 & 1.38 & 21.79 \\
200 & 18.2 & 0.76 & 14.91 & 0.67 & 9.98 \\
\hline
\end{tabular}

Table 2: Analysis of voltage, current and power under temperature changes at $1000 \mathrm{~W} / \mathrm{m}^{2}$.

\begin{tabular}{lccccr}
\hline Temperature ${ }^{o} \mathrm{C}$ & $\mathrm{V}_{o c}(\mathrm{~V})$ & $\mathrm{I}_{S C}(\mathrm{~A})$ & MPPT Voltage $(\mathrm{V})$ & MPPT Current $(\mathrm{A})$ & MPPT Power $(\mathrm{W})$ \\
\hline 0 & 22.76 & 3.63 & 19.44 & 3.38 & 65.70 \\
10 & 21.93 & 3.70 & 18.60 & 3.43 & 63.79 \\
20 & 21.12 & 3.76 & 17.76 & 3.47 & 61.62 \\
30 & 20.32 & 3.83 & 16.93 & 3.52 & 59.59 \\
40 & 19.49 & 3.89 & 16.10 & 3.56 & 57.31 \\
\hline
\end{tabular}

Table 3: Analysis of voltage, current and power under Shunt Resistance changes at $1000 \mathrm{~W} / \mathrm{m}^{2}$ and $25^{\circ} \mathrm{C}$..

\begin{tabular}{lccccr}
\hline Shunt Resistance $(\Omega)$ & Voc $(\mathrm{V})$ & ISC $(\mathrm{A})$ & MPPT Voltage $(\mathrm{V})$ & MPPT Current $(\mathrm{A})$ & MPPT Power $(\mathrm{W})$ \\
\hline 5 & 17.31 & 3.83 & 9.57 & 1.91 & 18.27 \\
10 & 19.42 & 3.83 & 15.11 & 2.25 & 33.99 \\
50 & 20.20 & 3.83 & 16.73 & 3.27 & 54.70 \\
100 & 20.27 & 3.83 & 16.85 & 3.41 & 57.45 \\
500 & 20.33 & 3.83 & 16.93 & 3.53 & 59.76 \\
\hline
\end{tabular}

Table 4: Analysis of voltage, current and power under Shunt Resistance changes at $1000 \mathrm{~W} / \mathrm{m}^{2}$ and $25^{\circ} \mathrm{C}$..

\begin{tabular}{lccccr}
\hline Irradiation Vs Shunt Resistance & $1000 \mathrm{~W} / \mathrm{m}^{2}$ & $800 \mathrm{~W} / \mathrm{m}^{2}$ & $600 \mathrm{~W} / \mathrm{m}^{2}$ & $400 \mathrm{~W} / \mathrm{m}^{2}$ & $200 \mathrm{~W} / \mathrm{m}^{2}$ \\
\hline 10 & $40.81 \mathrm{~W}$ & $40.25 \mathrm{~W}$ & $39.7 \mathrm{~W}$ & $39.15 \mathrm{~W}$ & $38.61 \mathrm{~W}$ \\
20 & $20.79 \mathrm{~W}$ & $20.51 \mathrm{~W}$ & $20.23 \mathrm{~W}$ & $19.96 \mathrm{~W}$ & $19.68 \mathrm{~W}$ \\
30 & $13.95 \mathrm{~W}$ & $13.76 \mathrm{~W}$ & $13.57 \mathrm{~W}$ & $13.39 \mathrm{~W}$ & $13.2 \mathrm{~W}$ \\
40 & $10.49 \mathrm{~W}$ & $10.35 \mathrm{~W}$ & $10.21 \mathrm{~W}$ & $10.07 \mathrm{~W}$ & $9.93 \mathrm{~W}$ \\
50 & $8.41 \mathrm{~W}$ & $8.29 \mathrm{~W}$ & $8.18 \mathrm{~W}$ & $8.07 \mathrm{~W}$ & $7.96 \mathrm{~W}$ \\
100 & $4.22 \mathrm{~W}$ & $4.16 \mathrm{~W}$ & $4.10 \mathrm{~W}$ & $4.05 \mathrm{~W}$ & $3.99 \mathrm{~W}$ \\
200 & $2.15 \mathrm{~W}$ & $2.08 \mathrm{~W}$ & $2.05 \mathrm{~W}$ & $2.03 \mathrm{~W}$ & $2.00 \mathrm{~W}$ \\
300 & $1.40 \mathrm{~W}$ & $1.38 \mathrm{~W}$ & $1.36 \mathrm{~W}$ & $1.34 \mathrm{~W}$ & $1.32 \mathrm{~W}$ \\
\hline
\end{tabular}

indicates that the efficiency of the power is reduced at low shunt resistances while at high values of shunt resistances the efficient improves. It is noteworthy that the current remains at the same value in all the cases, hence the value of the maximum power point increases with increase in the shunt resistance.

\subsection{Power Dissipation of Shunt Resistance}

Table 4 shows the variation of the Shunt Resistance against different levels of solar radiation. This represents a reduction of the efficiency due to the power loses inside the PV cell in the form of heat. Similarly, Figure 6, shows that the temperature affects the voltage value to a greater extent than the current, in this case as temperature increases, the power dissipated by the resistor reduces, this is because the voltage generated by the PV cell was less. On the case, where the temperature decreases the voltage increases, thus, making the power consumed by the resistor to increase. Table 5 shows the effect of temperature on the shunt resistance. Firstly, the variation of the resistance affects the value of the power consumed under different temperature, as the temperature increases the voltage value also decreases, this generates less power delivered by the PV cells. It was noted that the performance of the PV cell was better in low temperatures and high shunt resistance values.

Although the power consumed by the shunt resistance may be the result of the quality of the materials used in its manufacture, as an imperfection in the manufacture of the cell can create the scenario [15]. It is important not to exceed the allowed specified value as this could lead to low performance by the cell.

\subsection{Effects of Variation of Series Resistor}

In solar cells, series resistance variation is generated due to; the flow of current through the emitter and base of the solar cell; the resistance between the metal contact and the silicon and the resistance from the connections [15]. Thus, series resistor in high values can reduce the short circuit current. Fur- 
Table 5: Power Dissipate in shunt resistance under temperature changes. Appendix C.7

\begin{tabular}{lccccr}
\hline Temperature Vs Shunt Resistance & $0^{\circ} \mathrm{C}$ & $10^{\circ} \mathrm{C}$ & $20^{\circ} \mathrm{C}$ & $40^{\circ} \mathrm{C}$ & $50^{\circ} \mathrm{C}$ \\
\hline $10 \Omega$ & $45.22 \mathrm{~W}$ & $44.55 \mathrm{~W}$ & $43.23 \mathrm{~W}$ & $40.81 \mathrm{~W}$ & $36.64 \mathrm{~W}$ \\
$20 \Omega$ & $23.02 \mathrm{~W}$ & $22.68 \mathrm{~W}$ & $22.02 \mathrm{~W}$ & $20.79 \mathrm{~W}$ & $18.69 \mathrm{~W}$ \\
$30 \Omega$ & $15.44 \mathrm{~W}$ & $15.21 \mathrm{~W}$ & $14.77 \mathrm{~W}$ & $13.95 \mathrm{~W}$ & $12.54 \mathrm{~W}$ \\
$40 \Omega$ & $11.61 \mathrm{~W}$ & $11.44 \mathrm{~W}$ & $11.11 \mathrm{~W}$ & $10.49 \mathrm{~W}$ & $9.43 \mathrm{~W}$ \\
$50 \Omega$ & $9.30 \mathrm{~W}$ & $9.17 \mathrm{~W}$ & $8.90 \mathrm{~W}$ & $8.41 \mathrm{~W}$ & $7.56 \mathrm{~W}$ \\
$100 \Omega$ & $4.66 \mathrm{~W}$ & $4.60 \mathrm{~W}$ & $4.46 \mathrm{~W}$ & $4.22 \mathrm{~W}$ & $3.79 \mathrm{~W}$ \\
$200 \Omega$ & $2.33 \mathrm{~W}$ & $2.30 \mathrm{~W}$ & $2.23 \mathrm{~W}$ & $2.11 \mathrm{~W}$ & $1.90 \mathrm{~W}$ \\
$300 \Omega$ & $1.55 \mathrm{~W}$ & $1.52 \mathrm{~W}$ & $1.48 \mathrm{~W}$ & $1.40 \mathrm{~W}$ & $1.26 \mathrm{~W}$ \\
\hline
\end{tabular}
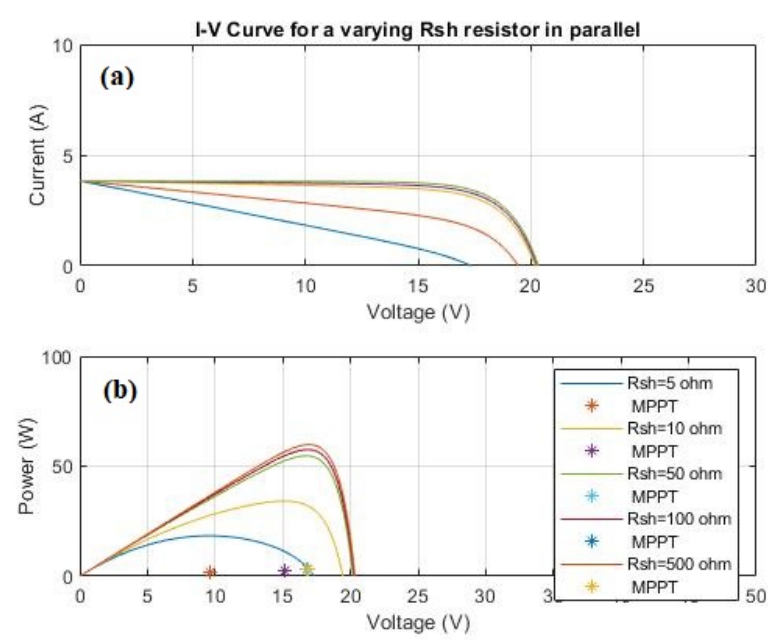

Figure 4: (a) I-V Curve for $\mathrm{R}_{s h}$ variable at STC (b)P-V Curve for $\mathrm{R}_{s h}$ variable at STC.

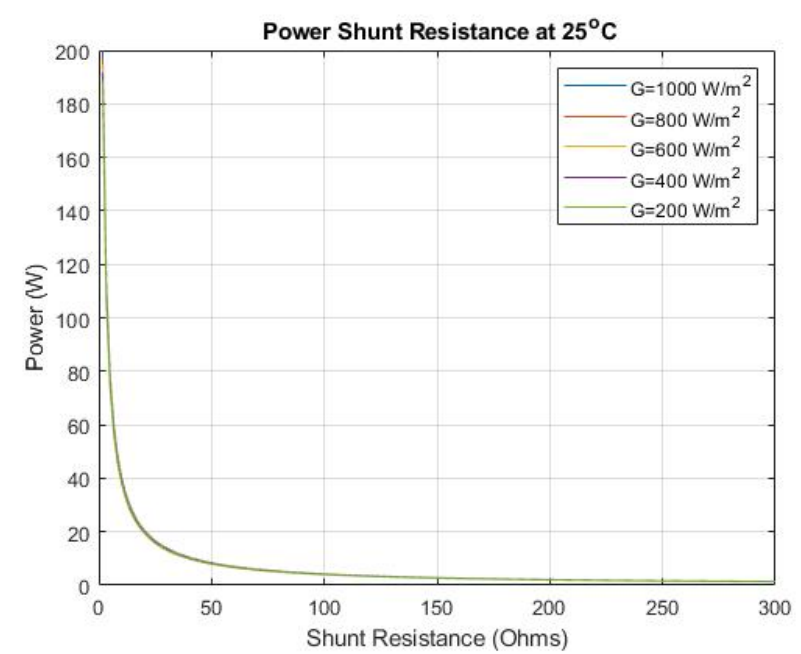

Figure 5: Power Dissipated of Shunt Resistance

thermore, the maximum percentage that can affect the variation of this values is $1.19 \%$ and less of $0.04 \%$ in nominal operating cell temperature and the values over $1.0 \Omega$ can be considered as high-power losses. Moreover, the age of the panel tends to increase the value of Rs hence it decreases the value of the $\mathrm{I}_{S C}$ [15]

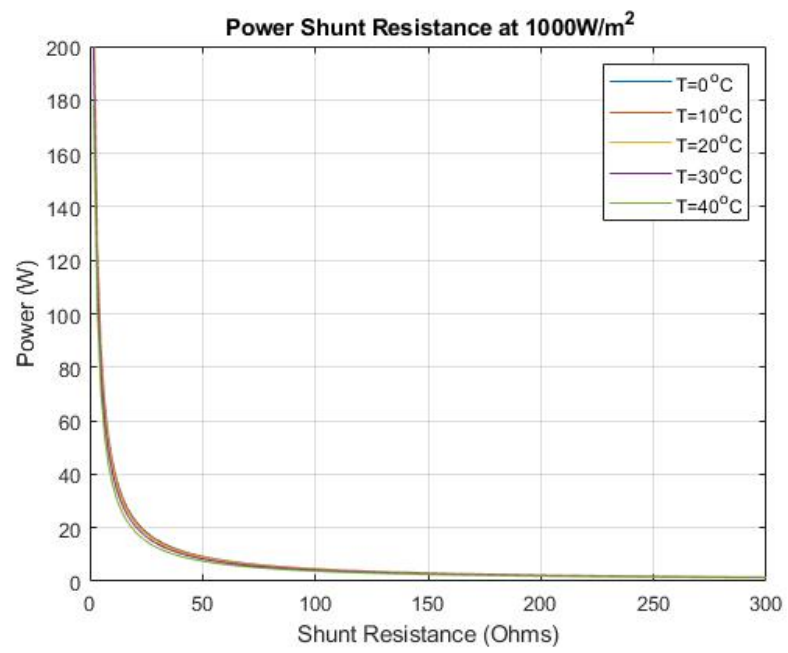

Figure 6: Power Dissipated of Shunt Resistance

Figure 7(a) corresponds to the change in the I-V curve when the value of the series resistor is varied, in this case values were varied between $0.001 \Omega$ to $0.180 \Omega$ and the slight change of the voltage was observed, while the current remains at the same value.
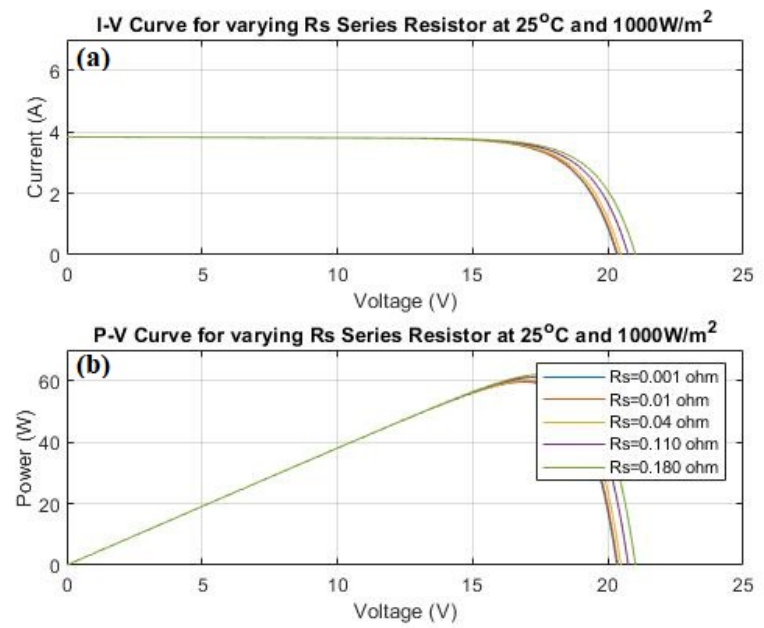

Figure 7: (a) I-V Curve for Rs Variable at STC (b) P-V Curve for Rs Variable at STC. 
In the case for the power values (Figure 7b), the difference in the value of voltage remains small, but can affect the value of the power in the same proportion. Table 6 is a comparison of the values of the different parameters when the series resistor changes. The power decreases in small values of the series resistor, but when the resistance is increased the power also increased.

The $\mathrm{I}_{s c}$ remains the same value, only the value of the voltage changes as Rs varies. In these parameters, the I-V and P-V curve have its characteristic shape from the behaviour of the power and voltage.

\subsection{Power Dissipation of Series Resistor}

Figures 8a represents the behaviour of the power with respect to the series resistor value. The value of the irradiance changes when the power is absorbed by the resistance. In this case, the power absorbed tends to reduce irradiance values, this is because the series resistor is small, and the Shunt resistance is relatively large, this allows more current to flow through series resistor path.
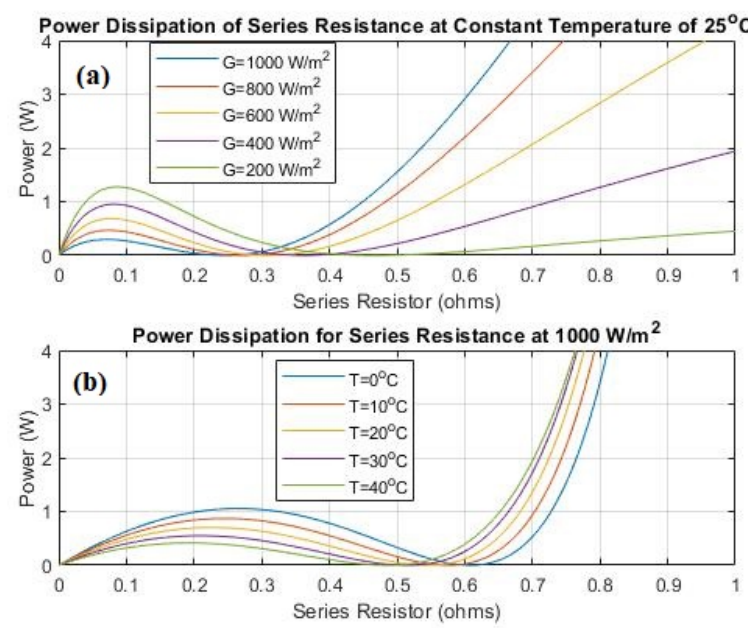

Figure 8: (a) Power Dissipated of Series Resistor at $25 ?^{\circ} \mathrm{C}$ (b) Power Dissipated of Series Resistor at $1000 \mathrm{~W} / \mathrm{m}^{2}$.

Table 7 shows the variation of the power regarding with respect to changing irradiation and series resistance. The power The power consumed between $0.0 \Omega$ and $0.4 \Omega$ were less despite the high value of irradiance variation. For the values above $0.4 \Omega$ the power consumed by the resistance increases in different proportions according to the resistance value, this represents the power lost, which can potentially affect the efficiency of the PV panel.

Figure $8 \mathrm{~b}$ shows the responses of the series resistor under different temperature changes; the power losses increase logarithmically at $0.7 \Omega$. The numerical values of the temperature variation on the series resistance (Table 8), between $0.0 \Omega$ and $0.06 \Omega$ exhibit a low power dissipation. As previously noted, the effect of the radiation and the temperature changes can affect the energy generation by a PV cell and the value of the power consumed by the series resistor can vary depending on weather conditions [16]. If these changing values are compared for all the figures the best recommendation range for less power consumption will be values under $0.5 \Omega$. Also, the worst case is at $1 \Omega$ where the power consumption is signifficant enough for any temperature changes. For this reason, it is important to control this value adequately because it can affect the performances of the PV cell by consuming energy that is delivered to the load. For the power lost based on the material properties, it is necessary to use conductors with less resistance to improve the flow of the electrons, and thus reduce the power consumed by the PV panel [16].

\section{Implementation and Analysis (Topological effects)}

The implementation of the topologies was conducted in stages, firstly, a PV system without a converter, this is to compare the power output of the PV module. Secondly, a PV system driven by PWM controller, this is to control the power output of the PV systems, and finally, the implementation with the MPPT using the $\mathrm{P} \& \mathrm{O}$ algorithm, to compare the performance of the different topologies. The methods were modelled and simulated by MATLAB-SIMULINK and the analysis of the behaviour of the signal (at some specific points) and the change in the variation of the temperature and irradiance conditions were investigated. Furthermore, an inquiry of the response time under different loads were also analysed.

\subsection{PV system without a boost converter}

To determine the values of the PV output under the temperature and irradiance changes with a constant load of $60 \Omega$, the PV Module was connected without a DC-DC converter (Figure 9): The obtained values (Table 9) from the PV module (Figure 10) and the signal produced by this model is shown in Figure 10, the analysis of the performance shows that changes in the values occurred after the first milliseconds of the test. This topology generates a maximum power of $6.97 \mathrm{~W}$ of $60 \mathrm{~W}$ available. Therefore, it can be considered that this topology has low efficacy at the beginning of implementation with $11.61 \%$ of the total energy that can be produced.

The result of this topology indicates that maximum power cannot be extracted when a PV panel is connected directly to the load. Apart from the low efficiency of this topology, it also reduces the time-life of the storage system due to the fluctuations in the charger.

\subsection{Pulse Width Modulation Controller (PWM) Method}

The PWM topology (Figure 11) was used to investigate the performance of the PWM under different weather conditions, In this case the PV was connected to a boost converter with a constant load resistance of $60 \Omega$ and a duty cycle value at $\mathrm{D}=$ 0.6478 .

The signals produced by the input of the PV panel and the output of the DC-DC converter when compare with the behaviour of the PV before and after the PWM was connected to the boost converter shows a low signals values at the beginning (table 10), except for the current, which was due to the 
Table 6: Under Series Resistance Changes at $1000 \mathrm{~W} / \mathrm{m}^{2}$ and $25^{\circ} \mathrm{C}$

\begin{tabular}{lccccr}
\hline Temperature Vs Shunt Resistance & $0^{\circ} \mathrm{C}$ & $10^{\circ} \mathrm{C}$ & $20^{\circ} \mathrm{C}$ & $30^{\circ} \mathrm{C}$ & $40^{\circ} \mathrm{C}$ \\
\hline $10 \Omega$ & $45.22 \mathrm{~W}$ & $44.55 \mathrm{~W}$ & $43.23 \mathrm{~W}$ & $40.81 \mathrm{~W}$ & $36.64 \mathrm{~W}$ \\
$20 \Omega$ & $23.02 \mathrm{~W}$ & $22.68 \mathrm{~W}$ & $22.02 \mathrm{~W}$ & $20.79 \mathrm{~W}$ & $18.69 \mathrm{~W}$ \\
$30 \Omega$ & $15.44 \mathrm{~W}$ & $15.21 \mathrm{~W}$ & $14.77 \mathrm{~W}$ & $13.95 \mathrm{~W}$ & $12.54 \mathrm{~W}$ \\
$40 \Omega$ & $11.61 \mathrm{~W}$ & $11.44 \mathrm{~W}$ & $11.11 \mathrm{~W}$ & $10.49 \mathrm{~W}$ & $9.43 \mathrm{~W}$ \\
$50 \Omega$ & $9.30 \mathrm{~W}$ & $9.17 \mathrm{~W}$ & $8.90 \mathrm{~W}$ & $8.41 \mathrm{~W}$ & $7.56 \mathrm{~W}$ \\
$100 \Omega$ & $4.66 \mathrm{~W}$ & $4.60 \mathrm{~W}$ & $4.46 \mathrm{~W}$ & $4.22 \mathrm{~W}$ & $3.79 \mathrm{~W}$ \\
$200 \Omega$ & $2.33 \mathrm{~W}$ & $2.30 \mathrm{~W}$ & $2.23 \mathrm{~W}$ & $2.11 \mathrm{~W}$ & $1.90 \mathrm{~W}$ \\
$300 \Omega$ & $1.55 \mathrm{~W}$ & $1.52 \mathrm{~W}$ & $1.48 \mathrm{~W}$ & $1.40 \mathrm{~W}$ & $1.26 \mathrm{~W}$ \\
\hline
\end{tabular}

Table 7: Power Dissipate in Series Resistance under Irradiance Changes

\begin{tabular}{lccccr}
\hline Irrad. Vs Shunt Resistance & $1000 \mathrm{~W} / \mathrm{m} 2$ & $800 \mathrm{~W} / \mathrm{m} 2$ & $600 \mathrm{~W} / \mathrm{m} 2$ & $400 \mathrm{~W} / \mathrm{m} 2$ & $200 \mathrm{~W} / \mathrm{m} 2$ \\
\hline 0.1 & $0.26 \mathrm{~W}$ & $0.43 \mathrm{~W}$ & $0.65 \mathrm{~W}$ & $0.92 \mathrm{~W}$ & $1.26 \mathrm{~W}$ \\
0.2 & $0.40 \mathrm{~W}$ & $0.10 \mathrm{~W}$ & $0.23 \mathrm{~W}$ & $0.43 \mathrm{~W}$ & $0.72 \mathrm{~W}$ \\
0.3 & $0.06 \mathrm{~W}$ & $0.01 \mathrm{~W}$ & $0.01 \mathrm{~W}$ & $0.06 \mathrm{~W}$ & $0.24 \mathrm{~W}$ \\
0.4 & $0.57 \mathrm{~W}$ & $0.38 \mathrm{~W}$ & $0.16 \mathrm{~W}$ & $0.02 \mathrm{~W}$ & $0.02 \mathrm{~W}$ \\
0.5 & $1.54 \mathrm{~W}$ & $1.15 \mathrm{~W}$ & $0.64 \mathrm{~W}$ & $0.21 \mathrm{~W}$ & $0.06 \mathrm{~W}$ \\
0.6 & $2.91 \mathrm{~W}$ & $2.20 \mathrm{~W}$ & $1.31 \mathrm{~W}$ & $0.53 \mathrm{~W}$ & $0.07 \mathrm{~W}$ \\
0.7 & $4.54 \mathrm{~W}$ & $3.40 \mathrm{~W}$ & $2.06 \mathrm{~W}$ & $0.90 \mathrm{~W}$ & $0.16 \mathrm{~W}$ \\
0.8 & $6.33 \mathrm{~W}$ & $4.68 \mathrm{~W}$ & $2.84 \mathrm{~W}$ & $1.27 \mathrm{~W}$ & $0.26 \mathrm{~W}$ \\
0.9 & $8.28 \mathrm{~W}$ & $5.99 \mathrm{~W}$ & $3.60 \mathrm{~W}$ & $1.61 \mathrm{~W}$ & $0.36 \mathrm{~W}$ \\
1 & $10.25 \mathrm{~W}$ & $7.29 \mathrm{~W}$ & $4.31 \mathrm{~W}$ & $1.93 \mathrm{~W}$ & $0.45 \mathrm{~W}$ \\
\hline
\end{tabular}

Table 8: Power Dissipate in Series Resistance Under Temperature Changes

\begin{tabular}{lccccc}
\hline Temp. Vs Shunt Resistance & $0^{\circ} \mathrm{C}$ & $10^{\circ} \mathrm{C}$ & $20^{\circ} \mathrm{C}$ & $30^{\circ} \mathrm{C} 40^{\circ} \mathrm{C}$ & \\
\hline 0.1 & $0.63 \mathrm{~W}$ & $0.55 \mathrm{~W}$ & $0.48 \mathrm{~W}$ & $0.40 \mathrm{~W}$ & $0.32 \mathrm{~W}$ \\
0.2 & $0.98 \mathrm{~W}$ & $0.84 \mathrm{~W}$ & $0.69 \mathrm{~W}$ & $0.54 \mathrm{~W}$ & $0.41 \mathrm{~W}$ \\
0.3 & $1.03 \mathrm{~W}$ & $0.82 \mathrm{~W}$ & $0.63 \mathrm{~W}$ & $0.45 \mathrm{~W}$ & $0.30 \mathrm{~W}$ \\
0.4 & $0.77 \mathrm{~W}$ & $0.54 \mathrm{~W}$ & $0.35 \mathrm{~W}$ & $0.20 \mathrm{~W}$ & $0.10 \mathrm{~W}$ \\
0.5 & $0.32 \mathrm{~W}$ & $0.15 \mathrm{~W}$ & $0.05 \mathrm{~W}$ & $0.005 \mathrm{~W}$ & $0.004 \mathrm{~W}$ \\
0.6 & $0.002 \mathrm{~W}$ & $0.02 \mathrm{~W}$ & $0.11 \mathrm{~W}$ & $0.25 \mathrm{~W}$ & $0.39 \mathrm{~W}$ \\
0.7 & $0.52 \mathrm{~W}$ & $0.93 \mathrm{~W}$ & $1.35 \mathrm{~W}$ & $1.72 \mathrm{~W}$ & $1.94 \mathrm{~W}$ \\
0.8 & $3.44 \mathrm{~W}$ & $4.43 \mathrm{~W}$ & $5.27 \mathrm{~W}$ & $5.76 \mathrm{~W}$ & $5.78 \mathrm{~W}$ \\
0.9 & $11.51 \mathrm{~W}$ & $13.35 \mathrm{~W}$ & $14.49 \mathrm{~W}$ & $14.66 \mathrm{~W}$ & $13.73 \mathrm{~W}$ \\
1 & $30.31 \mathrm{~W}$ & $32.70 \mathrm{~W}$ & $33.59 \mathrm{~W}$ & $32.23 \mathrm{~W}$ & $28.78 \mathrm{~W}$ \\
\hline
\end{tabular}

Table 9: Parameter values obtained at the beginning of the test

\begin{tabular}{lccccccr}
\hline Time (s) & 0.000 & 0.005 & 0.010 & 0.015 & 0.020 & 0.025 & 0.030 \\
Power (W) & 0.00 & 0.63 & 2.46 & 5.06 & 6.68 & 6.96 & 6.97 \\
Current (A) & 0.00 & 0.10 & 0.20 & 0.29 & 0.33 & 0.34 & 0.34 \\
Voltage (V) & 0.00 & 6.30 & 12.30 & 17.95 & 20.26 & 20.49 & 20.51 \\
\hline
\end{tabular}




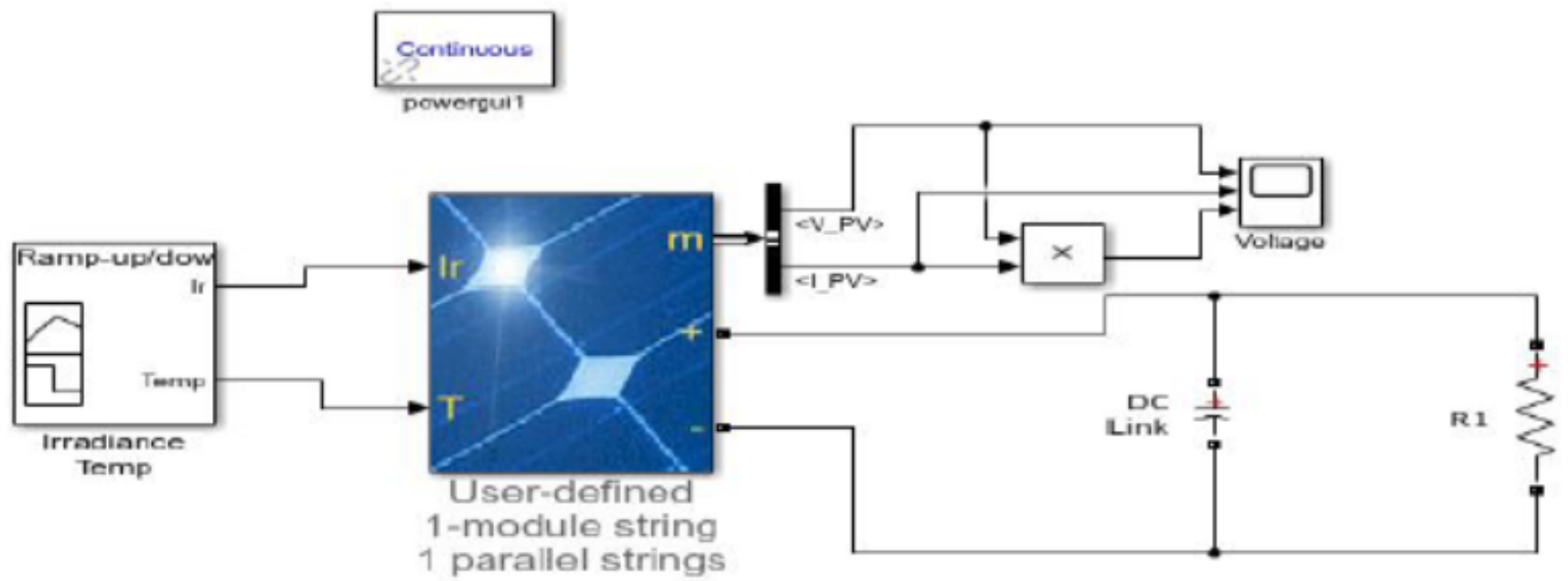

Figure 9: PV Module without a boost Converter [17].

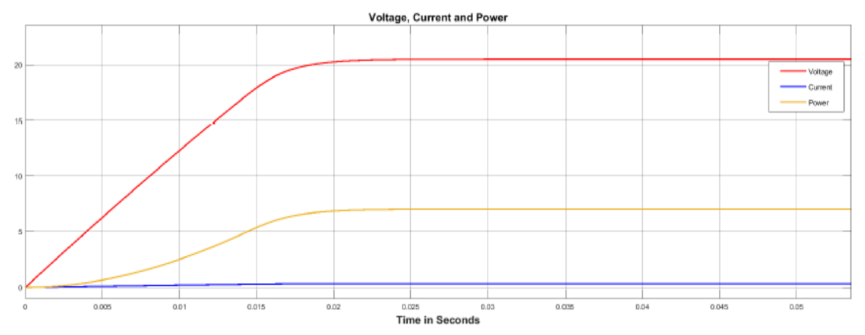

Figure 10: Behaviour of PV Without a Boost .

fixed irradiance value during simulation. The power increases up to $49.04 \mathrm{~W}$ and remains around at this value until the next change of irradiance.

The output of the boost converter reduces the value of the current to increase the voltage. The power output that delivers this method increases if compared with the topology earlier mentioned.

The variations (Figure 12) were observed from $40^{\circ} \mathrm{C}$ to $35^{\circ} \mathrm{C}$ at $800 \mathrm{~W} / \mathrm{m}^{2}$. These values remain the same with a less modification, since the temperature changes within time lag were quite negligible as such the parameters have less effect than the irradiance changes in the power. Table 11 and (12) shows parameter values under temperature change and under irradiance change.

The voltage and current input responded differently under the irradiance changes (Table 12). The most significant change occurred in the power output, due to the abrupt change in the current, which is generated by the irradiance that passes from $1000 \mathrm{~W} / \mathrm{m}^{2}$ to $800 \mathrm{~W} / \mathrm{m}^{2}$ as the voltage decreases. These values were found to affect the power output directly, as the converter maintains voltage value. The power output (level) was minimally affected by the changes in the current, which resulted in slow response time and stable power level, which is important for the storage system.

\subsection{MPPT Control System}

In the MPPT (topology) control system (Figure ??), the boost converter was implemented and controlled by the algorithm called Perturb and Observes (P \& O), which controls the duty cycle to achieve the maximum point. In this topology, the power output under different climatological conditions were evaluated and the behaviour of the signals from the PV and the Boost converter were analysed.

In Figure 14, the power increases to a maximum level point (highest power output value) and after some fluctuations became stable, the voltage input generated by the PV panel work well on the maximum value as the output voltage increases to $60 \mathrm{~V}$. this power point was achieved as a result of the boost converter implementation. Apparently, as the voltage increases, it becomes evident that the PV current decreases in a steady manner without fluctuations.

Also, Figure 15 shows the variation of the signals due to the temperature changes, in this case, the temperature decreases from $40^{\circ} \mathrm{C}$ to $30^{\circ} \mathrm{C}$ with a sudden increase in the input power from $56 \mathrm{~W}$ to $58 \mathrm{~W}$. The output power signal reacts slowly to these changes as the MPPT tracks the maximum power based on the input signal.

The change in the irradiance is an essential factor to consider on PV panels with the MPPT implementation. This factor (Figure 16) shows that the output and input signals of the model could change under the influence of irradiance. The power input drop abruptly because the irradiance varies from $1000 \mathrm{~W} / \mathrm{m}^{2}$ to $800 \mathrm{~W} / \mathrm{m}^{2}$, this difference is due to the change in the PV current, that is the current is most affected by irradiance change while the voltage has a very slight change. Concerning the output signals, the voltage remains at the highest possible value, and the MPPT tract the power output at the highest point available under these conditions. The change in the output does not occur spontaneously it takes a time lag to achieve the maximum possible level under such weather conditions. Also, the signal has no sudden changes due to the irradiance variation.

The implementation of the boost converter controlled by an MPPT algorithm offers the best way to extract the maximum 


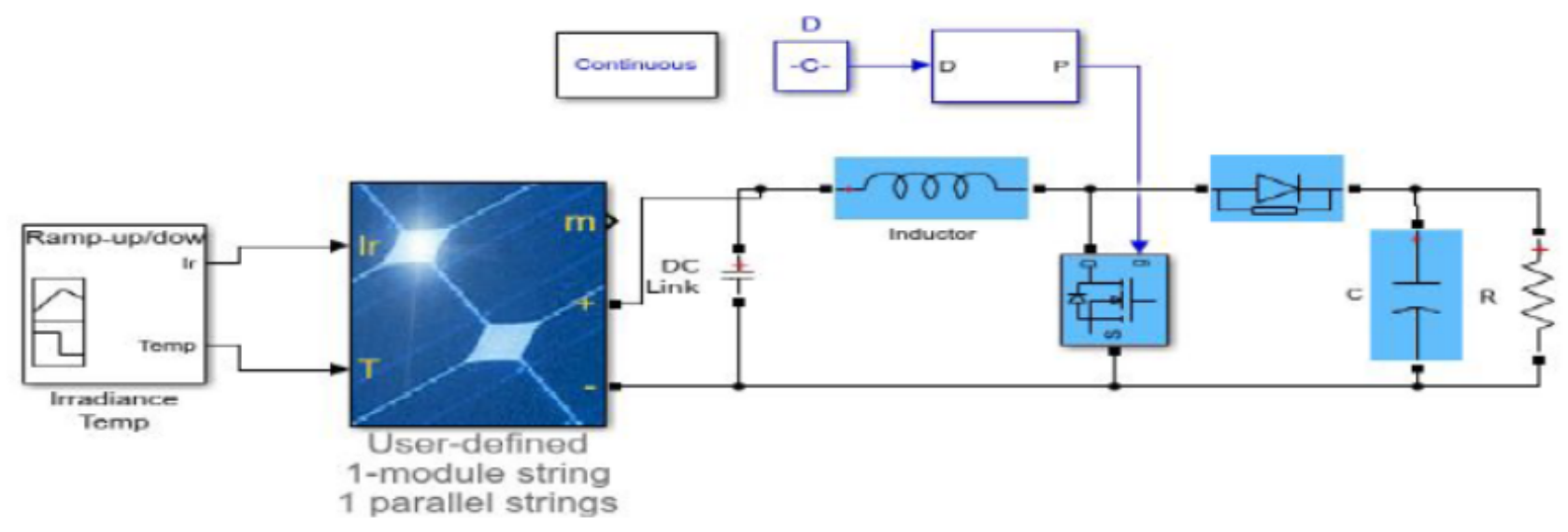

Figure 11: PWM Controller Topology [17].

Table 10: Parameter vales generated at the beginning of the test

\begin{tabular}{lccccccr}
\hline Time (s) & 0.00 & 0.005 & 0.010 & 0.015 & 0.020 & 0.025 & 0.030 \\
PV Power (W) & 0.00 & 31.54 & 44.72 & 47.72 & 48.49 & 48.82 & 49.04 \\
PV Voltage (V) & 0.00 & 8.62 & 12.22 & 12.94 & 13.25 & 13.34 & 13.4 \\
PV Current (A) & 3.66 & 3.66 & 3.66 & 3.66 & 3.66 & 3.66 & 3.66 \\
Output Power (W) & 0.00 & 8.78 & 24.60 & 34.89 & 40.82 & 43.35 & 44.64 \\
Output Current (A) & 0.00 & 0.38 & 0.64 & 0.76 & 0.82 & 0.85 & 0.86 \\
Output Voltage (V) & 0.00 & 23.12 & 38.45 & 45.92 & 49.79 & 51.00 & 51.91 \\
\hline
\end{tabular}

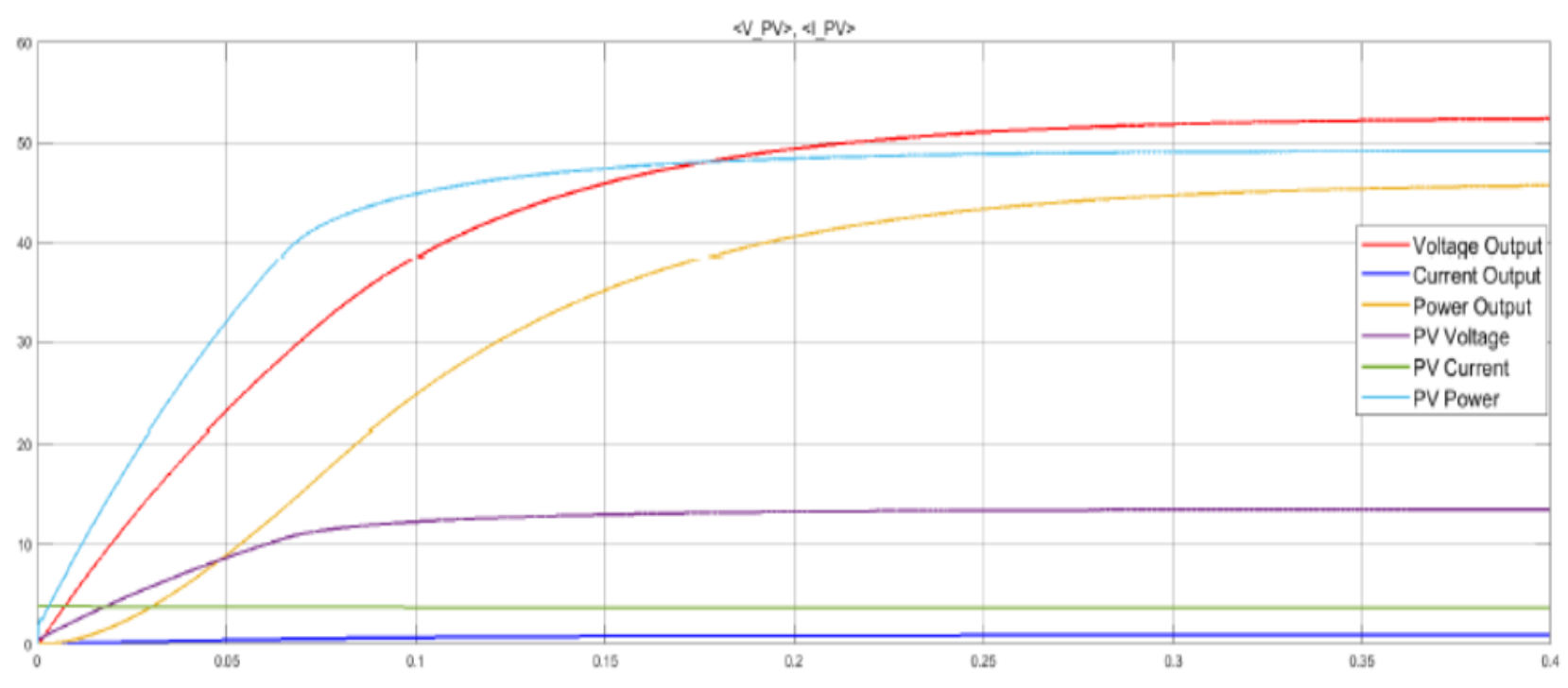

Figure 12: Variation of Voltage, Current and Power etc generated at the Start of the test

power available in the system, and the implemented algorithm works to find the optimal point available despite the temperature and the irradiance changes. On the results of this model implemented, this topology (MPPT) is the most efficient way to achieve the maximum performance from PV panels because it reaches a high efficiency of the power output. Moreover, this system can reduce the time required to fully charge the stor- age system due to the voltage optimal point level. The best performance of this system is in temperatures under 40 Celsius degrees, as we can see in the Figure $4 b$, the reduction of the temperature increased the power output.

\subsection{Comparison of Model Topologies}

Every topology has a different efficiency in the power that it delivered. Figure 16 shows a comparison of the three-topology 
Table 11: parameter values under temperature

\begin{tabular}{lcccr}
\hline Time (s) & 3.32 & 3.33 & 3.34 & 3.35 \\
PV Power (W) & 32.60 & 32.60 & 32.43 & 32.43 \\
PV Voltage (V) & 10.94 & 10.94 & 10.92 & 10.92 \\
PV Current (A) & 2.98 & 2.98 & 2.97 & 2.97 \\
Output Power (W) & 30.35 & 30.36 & 30.35 & 30.35 \\
Output Current (A) & 0.71 & 0.71 & 0.71 & 0.71 \\
Output Voltage (V) & 42.76 & 42.77 & 42.76 & 42.74 \\
\hline
\end{tabular}

Table 12: parameter values under irradiance change

\begin{tabular}{lccccccr}
\hline Time (s) & 2.00 & 2.05 & 2.10 & 2.15 & 2.20 & 2.25 & 2.30 \\
PV Power (W) & 49.37 & 33.62 & 33.11 & 32.78 & 32.75 & 32.69 & 32.63 \\
PV Voltage (V) & 13.49 & 11.32 & 11.15 & 11.04 & 10.99 & 10.97 & 10.95 \\
PV Current (A) & 3.66 & 2.97 & 2.97 & 2.97 & 2.98 & 2.98 & 2.98 \\
Output Power (W) & 46.68 & 38.87 & 34.69 & 32.27 & 31.29 & 30.60 & 30.48 \\
Output Current (A) & 0.88 & 0.80 & 0.76 & 0.73 & 0.72 & 0.71 & 0.71 \\
Output Voltage (V) & 53.05 & 48.59 & 45.65 & 44.21 & 43.47 & 43.11 & 42.93 \\
\hline
\end{tabular}

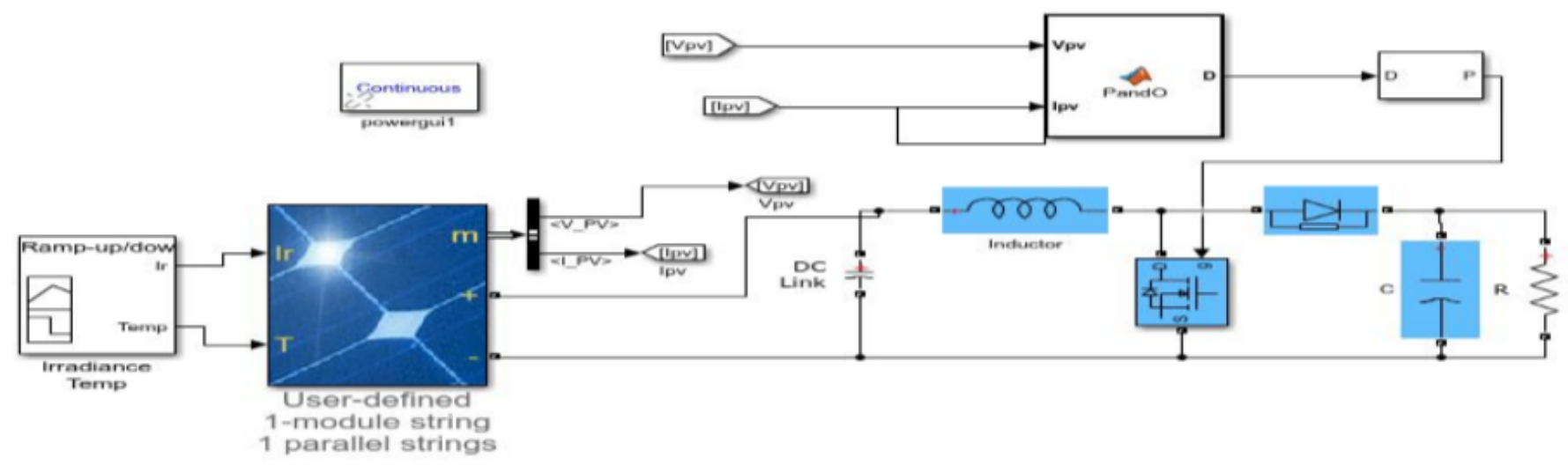

Figure 13: MPPT Simulation Model [17]

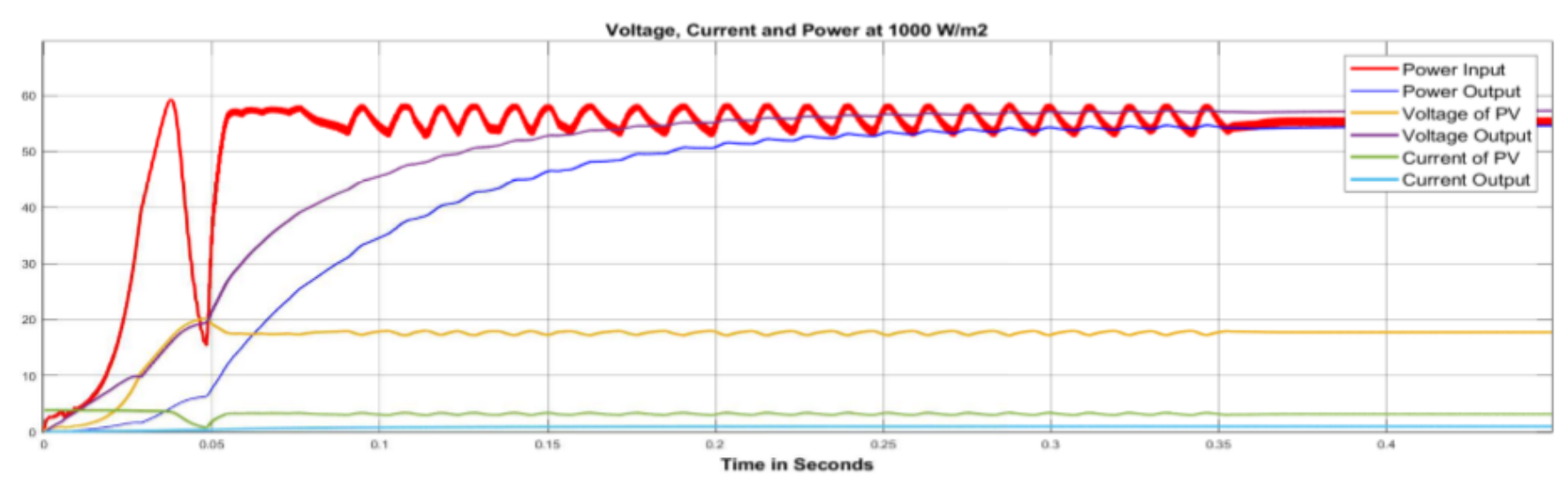

Figure 14: Signals variation for the MPPT in the PV system

used under the same weather conditions at the same time. Also, Table 13 is shown the numerical values of the comparison at the time of one second.

The power delivery for the MPPT is the highest, it is $10.64 \%$ higher than the PWM power output and $86.17 \%$ greater than the PV without control. These results show that the output energy performance of MMPT under different technologies is more efficient. 


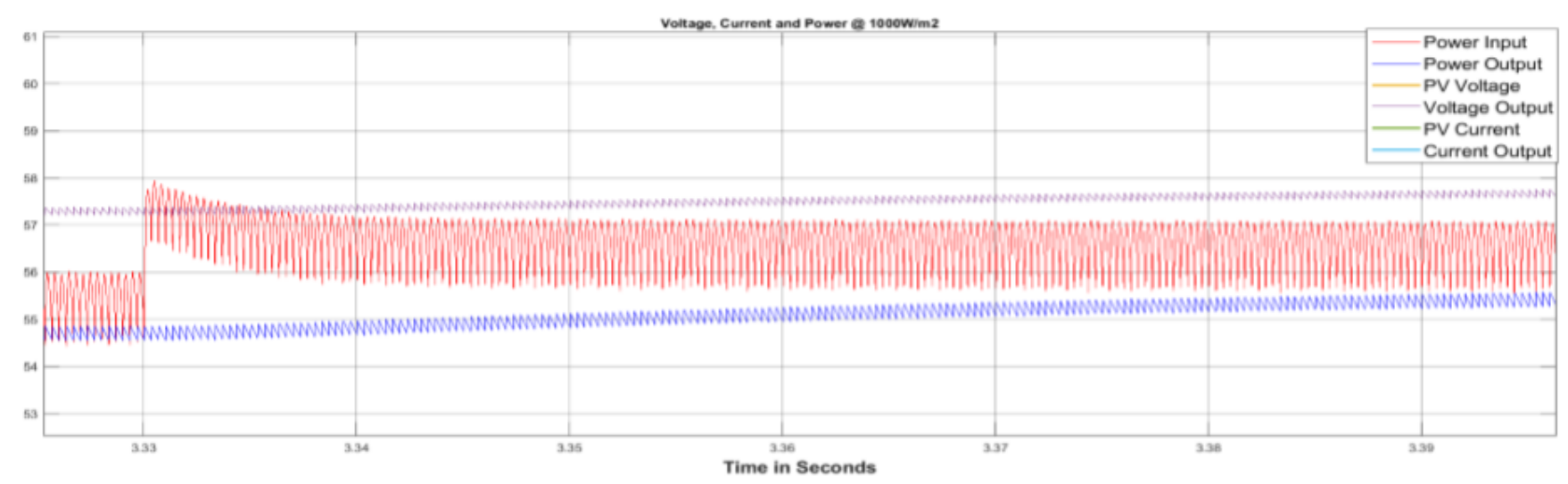

Figure 15: Implementation of the MPPT in PV System with variable temperature

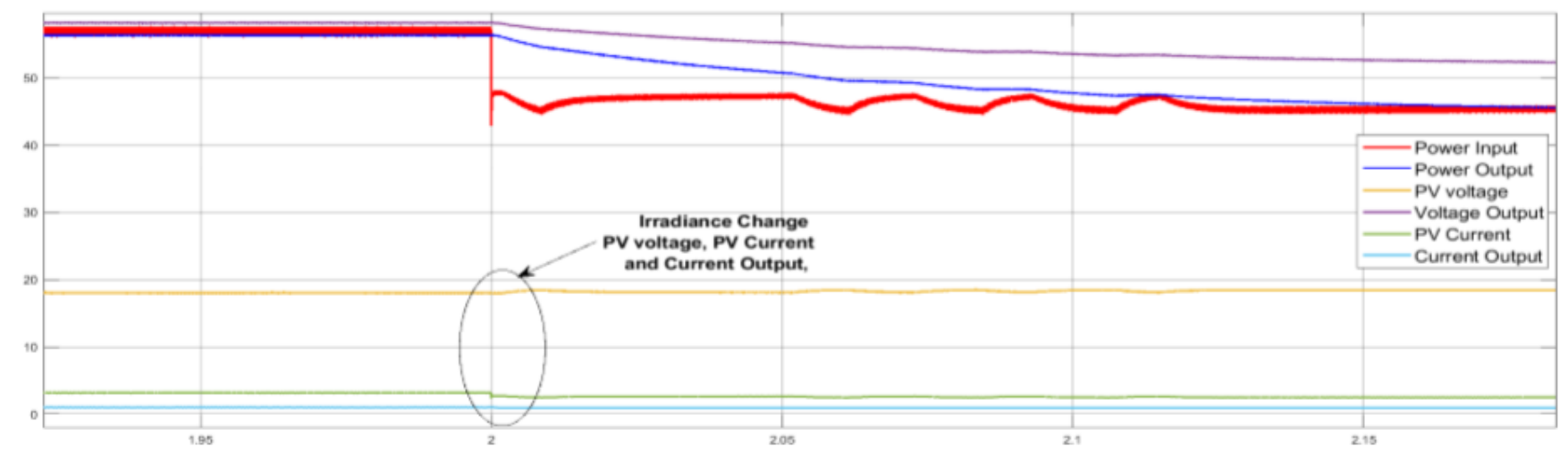

Figure 16: MPPT Implementation on the PV System under irradiance change

The implementation of the boost converter by a PWM controller tend to improve the efficacy of the energy delivered by the PV panel. In the MPPT topology, power of $44.64 \mathrm{~W}$ was realized under the same conditions without sudden fluctuations and more stable signals. However, the implementation of the boost converter controller by an MPPT with a P\&O algorithm is the most efficient of the three topologies used to control the system, reaching $51.20 \mathrm{~W}$, that is the energy that the system can deliver under the climate conditions at one second.

\subsection{5 MPPT under different loads}

The response time of the MPPT under three different loads (20 $\Omega, 60 \Omega$ and $100 \Omega$ ) were examined, in order to understand the behaviour of the power output when an unexpected change of temperature or irradiance occurred that may affect its value. Therefore, the behaviour of the input and output power under di?erent loads were investigated, and the results (Table 14), shows that, as the input power changes suddenly within $3.33 \mathrm{sec}$, the signal stabilizes rapidly. While, the power output signal takes a time of $3.2 \mathrm{sec}$. to reach a stable value after a change in the input signal, this corresponds to the time that the MPPT takes to find the maximum point under a perturbation in the input signal, this process consists of sending the optimal duty cycle to the boost converter that calculate the algorithm and instruct the switching between on and off to control the inductance in reaching the optimal power of delivery.

In the case of $60 \Omega$ load, the temperature changes at a time of 3.33s (Seesupplementary material Figure 17). The Figure 18 represents the input and output power signals under a load of 20 $\Omega$, this shows an abrupt temperature change to MPPT response. The MPPT tracks the power input and stabilises the power output after $3.36 \mathrm{~s}$ to remain constant until a new variation. Also, the variation of the load at $60 \Omega$ is in the Figure 19 of the supplementary material, shows the maximum value for the load in the converter and after the perturbation in the input signal the power output responds in a fraction of time, and after $3.4 \mathrm{~s}$ it reaches a constant value close to the power input. These behaviour in the time lapse is consistence with the values in Table 6. Similarly, in the Figure 20 (supplementary material), under the effect of $100 \Omega$ load, the power input response time was slower and not close to the maximum power point, hence, the efficiency of the MPPT at this point was reduced (Table 14).

\section{Conclusion}

From the foregoing analysis, three different topologies has been used to achieve an optimal power point on the I-V curve 
Table 13: Power Comparison of Topologies at $1000 \mathrm{~W} / \mathrm{m}^{2}$ and $25^{\circ} \mathrm{C}$

\begin{tabular}{lccr}
\hline Topology & PV & PWM & MPPT \\
Voltage (V) & 20.50 & 51.31 & 55.66 \\
Current (A) & 0.34 & 0.87 & 0.92 \\
Power (W) & 6.97 & 44.64 & 51.20 \\
\hline
\end{tabular}

Table 14: Response time of the MPPT under different Loads

\begin{tabular}{lccccccr}
\hline Time $(\mathrm{s})$ & 3.32 & 3.34 & 3.36 & 3.38 & 3.4 & 3.42 & 3.44 \\
\hline Input $20 \Omega$ & $54.10 \mathrm{~W}$ & $54.80 \mathrm{~W}$ & $54.72 \mathrm{~W}$ & $54.40 \mathrm{~W}$ & $54.37 \mathrm{~W}$ & $54.36 \mathrm{~W}$ & $54.33 \mathrm{~W}$ \\
Output $20 \Omega$ & $53.12 \mathrm{~W}$ & $53.23 \mathrm{~W}$ & $53.31 \mathrm{~W}$ & $53.46 \mathrm{~W}$ & $53.57 \mathrm{~W}$ & $53.60 \mathrm{~W}$ & $53.62 \mathrm{~W}$ \\
Input $40 \Omega$ & $55.50 \mathrm{~W}$ & $56.10 \mathrm{~W}$ & $55.94 \mathrm{~W}$ & $55.80 \mathrm{~W}$ & $55.77 \mathrm{~W}$ & $55.75 \mathrm{~W}$ & $55.74 \mathrm{~W}$ \\
Output $40 \Omega$ & $54.70 \mathrm{~W}$ & $54.83 \mathrm{~W}$ & $54.96 \mathrm{~W}$ & $55.00 \mathrm{~W}$ & $55.10 \mathrm{~W}$ & $55.12 \mathrm{~W}$ & $55.15 \mathrm{~W}$ \\
Input $60 \Omega$ & $55.00 \mathrm{~W}$ & $55.70 \mathrm{~W}$ & $55.54 \mathrm{~W}$ & $55.37 \mathrm{~W}$ & $55.35 \mathrm{~W}$ & $55.33 \mathrm{~W}$ & $55.32 \mathrm{~W}$ \\
Output $60 \Omega$ & $53.82 \mathrm{~W}$ & $53.85 \mathrm{~W}$ & $53.90 \mathrm{~W}$ & $53.93 \mathrm{~W}$ & $53.90 \mathrm{~W}$ & $54.00 \mathrm{~W}$ & $54.04 \mathrm{~W}$ \\
\hline
\end{tabular}

from PV system from the less to the most efficient way of connection. Firstly, the PV panel was connected directly to the load without a control boost converter and the results shows a reduced lifetime storage for the system, which cannot be said to be efficient.

Secondly, the system was connected to boost converter and controlled by PWM controller, in this case, the efficiency increases but it does not reach the maximum power point, because the PWM has a ?x duty cycle to generate a PWM pulse. This method is useful for small applications where it is not necessary to get the maximum power available because the energy needed by the load is reached without a boost, and enough for the use required.

Finally, the MPPT Technique was implemented using the algorithm $\mathrm{P} \& \mathrm{O}$, this delivered more power because it tracks the optimal point to get the maximum energy available in every moment, this method is recommended for a large system where it is crucial to get the maximum power available, usually for storage because the implementation can reduce the storage size and the time of charge. However, the topology is not fast enough to respond to ambient changes, due to it continuous tracking for the changes in the signal to adjust to the optimal point, which takes time to reach the value.

\section{References}

[1] K. Srikumar \& C. Saibabu, "A system and novel methodology to track maximum power from photo voltaic system: A comparative and experimental analysis", Journal of King Saud University - Engineering Sciences (2018), https://doi.org/10.1016/j.jk.

[2] E. T. Djamel, B. Achour, S. Atallah \& A. Tayeb, "Improved Performance of a Photovoltaic Panel by MPPT Algorithms", (2019) http://dx.doi.org/10.5772/intechopen.79709

[3] Orabi M, Hilmy F, Shawky A, Jaber AAQ, Hasaneen E, Gomaa E. Onchip integrated power management MPPT controller utilizing cell-level architecture for PV solar system. Solar Energy. 2015;117:10-28

[4] T. Esram \& P. L. Chapman, "Comparison of photovoltaic array maximum power point tracking techniques", IEEE Transactions on energy conversion 22 (2007) 439.
[5] S. A. Sharaf Eldin, M. S. Abd-Elhady, "Kandil HA. Feasibility of solar tracking systems for PV panels in hot and cold regions", Renewable Energy 85 (2016) 228.

[6] A. Ingegnoli \& A. Iannopollo, "A maximum power point tracking algorithm for stand-alone photovoltaic systems controlled by low computational power devices", 15th IEEE 2010 Mediterranean Electro-Technical Conference; 26-28 April 2010 Valletta, Malta: IEEE. pp. 1522-1527

[7] D. Alex \& J. Berclin, "Modeling and simulation of photovoltaic module in matlab", Proceedings of International Conference on Applied Mathematics and Theoretical Computer Science, (ISBN 978-93-82338-35-2), 2013.

[8] M. Rashid, "Alternative energy in power electronics", Butterworth Heinemann, Amsterdam Boston, 2015.

[9] E. Saloux, A. Teyssedou \& M. Sorin, "Explicit model of photo voltaic panels to determine voltages and currents at the maximum power point", Solar Energy 85 (2011) 713,

[10] D. Sera, R. Teodorescu \& P. Rodriguez, "Pv panel model based on datasheet values", IEEE International Symposium on Industrial Electronics, 2007.

[11] D. Bonkoungou, Z. Koalaga \& D. Njomo, "Modelling and simulation of photovoltaic module considering single-diode equivalent circuit model in matlab", International Journal of Emerging Technology and Advanced Engineering 3 (2013) 499.

[12] A. M. Bagher, "Types of solar cells and application", American Journal of Optics and Photonics 3 (2015) 94,.

[13] M. F. Nayan and S. M. S. Ullah. Modelling of solar cell characteristics considering the effect of electrical and environmental parameters. In 2015 3rd International Conference on Green Energy and Technology (ICGET), $1-6$,

[14] SFgate The effects of temperature on solar panel power production 2018", www.homeguides.sfgate.com .

[15] G. Saikrishna, S. K. Parida \& R. K. Behera, "Effect of parasitic resistance in solar photovoltaic panel under partial shaded condition”, 2015 International Conference on Energy Systems and Applications, pages 396-401, http:1eeexplore.ieee.org.

[16] P. Singh \& N. M. Ravindra. Analysis of series and shunt resistance in silicon solar cells using single and double exponential models. Emerging Materials Research, 1 (2012) 33.

[17] P. Giroux, G. Sybille, C. Osorio \& S. Chandrachood, "Detailed model of a $100 \mathrm{kw}$ grid connected PV array Matlab and Simulink Mathworks", United kingdom, 2018. 
Supplementary Materials

Table 15: Solarex MSX-60 specifications $\left(1 \mathrm{~kW} / \mathrm{m}^{2}, 25^{\circ} \mathrm{C}\right)$ [11]

\begin{tabular}{lr}
\hline Characteristics & Specifications \\
\hline Maximum power point $\left(P_{m p p}\right)$ & $60 \mathrm{~W}$ \\
Maximum Voltage $V_{m p p}$ & $17.1 \mathrm{~V}$ \\
Maximum Current $I_{m p p}$ & $3.5 \mathrm{~A}$ \\
Short-Circuit Current $I_{S C}$ & $3.8 \mathrm{~A}$ \\
Open Circuit Voltage $V_{O C}$ & $21.1 \mathrm{~V}$ \\
Temperature Coefficient of Open-Circuit Voltage $K_{V}$ & $-(80 \pm 10) \mathrm{mv} /{ }^{\circ} \mathrm{C}$ \\
Temperature Coefficient of Short-Circuit Current $K_{l}$ & $(0.065 \pm 0.1) \% /{ }^{\circ} \mathrm{C}$ \\
Approximate Effect of Temperature on power & $-(0.5 \pm 0.015) \% /{ }^{\circ} \mathrm{C}$ \\
Nominal operating cell Temperature (NOCT) & $47 \pm 2{ }^{\circ} \mathrm{C}$ \\
\hline
\end{tabular}

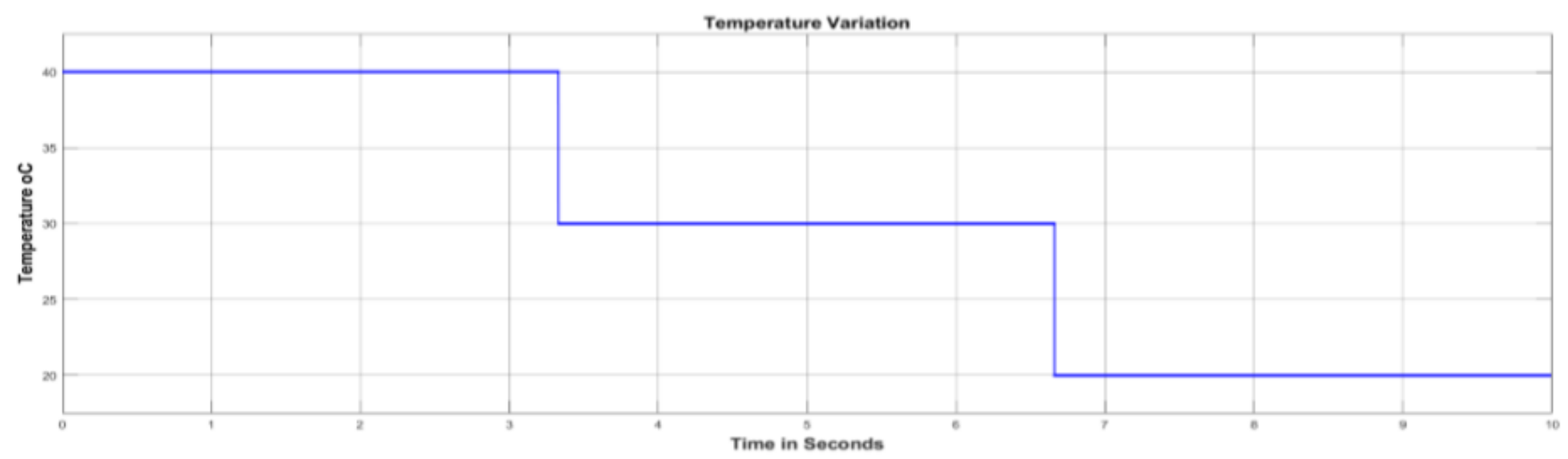

Figure 17: Simulation of Temperature Variations

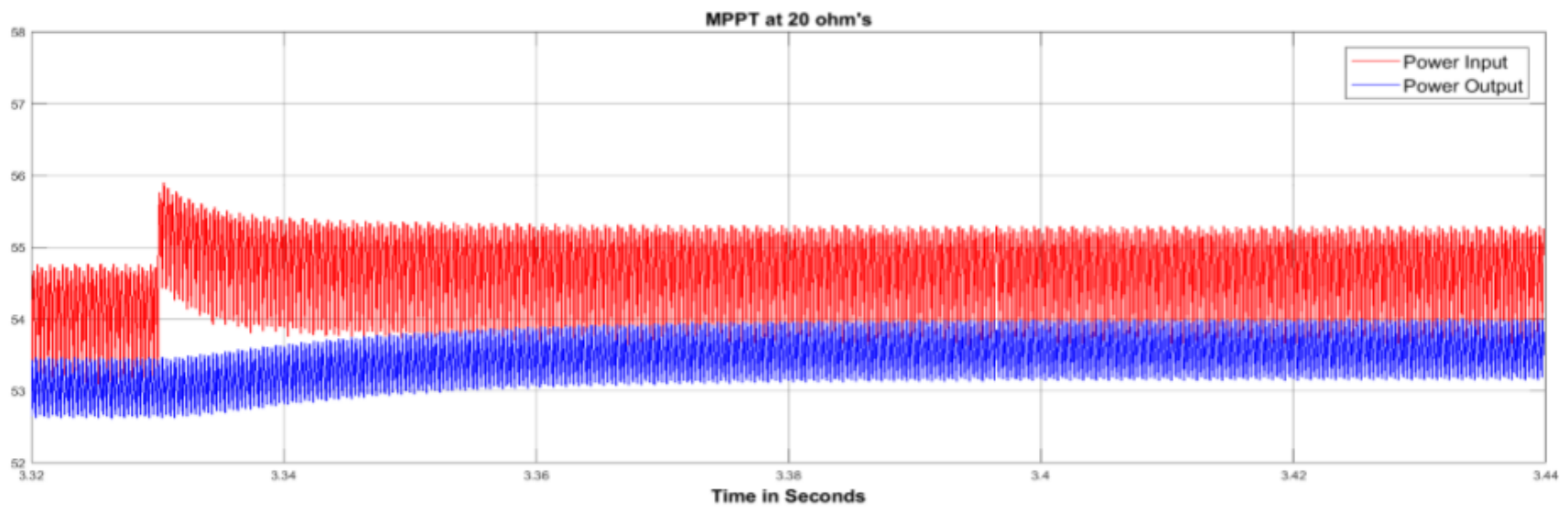

Figure 18: MPPT at load of $20 \Omega$ 


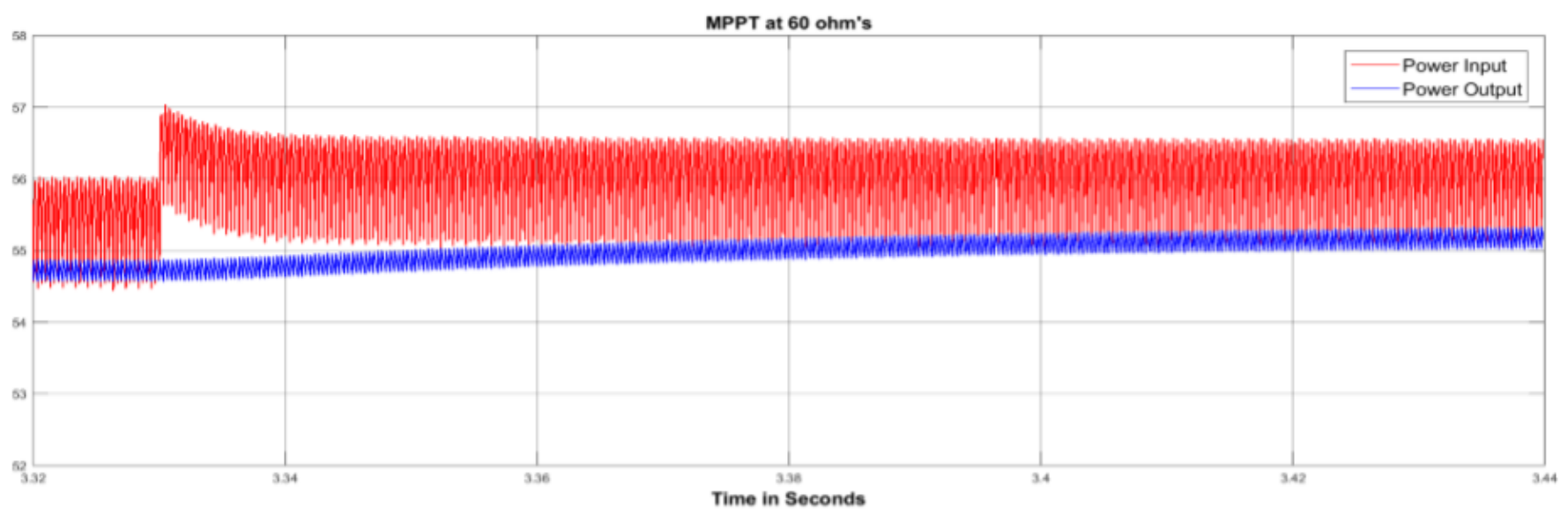

Figure 19: MPPT at load of $60 \Omega$

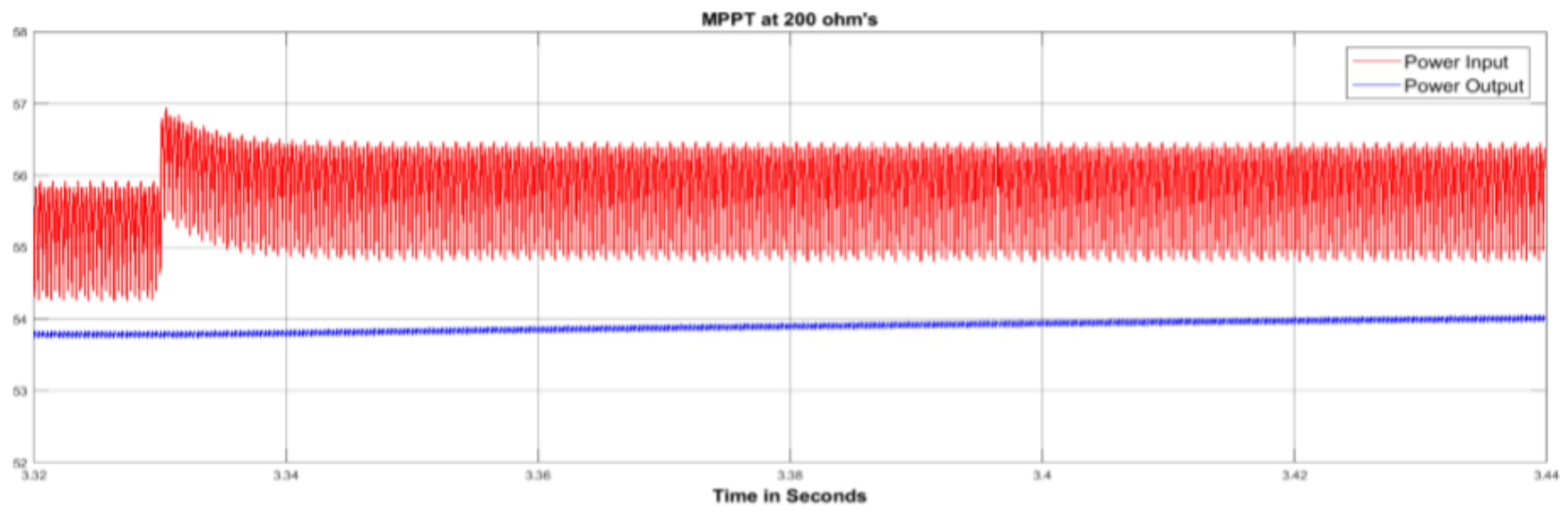

Figure 20: MPPT at load of $60 \Omega$ 